Egypt. Acad. J. biolog. Sci., 4 (1): 163-174 (2010)

Email: egyptianacademic@yahoo.com

Received: $21 / 6 / 2011$
A. Entomology

ISSN: $1687-8809$

www.eajbs.eg.net

\title{
Ecological aspects of Sassetia spp. ( Coccidae: Coccoidae: Hemiptera) and thier natural enemies in Egypt
}

\author{
Hoda Badary \\ Plant Protection Research Institute, Agriculture Research Center, Dokki, Giza, Egypt
}

\section{ABSTRACT}

In Egypt, Saissetia spp. (Coccidae: Coccoidae: Hemiptera) are the most dangerous soft scale insects infesting fruit trees. The aim of this work is to study the ecological aspects of Saissetia spp. and its natural enemies in Egypt. The result indicated that Genus Saissetia Deplanche comprises here by two species These are the soft brown scale, Saissetia coffeae (Walker) and the Mediterranean black scale, Saissetia oleae (Olvier). Genus Saissetia recorded here associated with 14 parasitoid species and 16 predator species. The seasonal abundance of $S$. coffeae was studied for two successive years from 2009-2010 on olive trees in Northern Coast .The obtained results showed that, the insect population reached maximum during mid September (7728 and 8368/ 60 leaves/30 twigs) in first year and second year, respectively. Numbers by parasitoids Metaphycus lounsburyi (Howard), Microterys flavus (Howard) and Scutellista cyanea Motschulsky and a predator Scymnus syriacus Mars., reached maximum (31,9,3, and19/60 leaves/30 twigs) during September, July, September and August, in the first year, respectively and 20,8,2 and 15 during September in the second year, respectively. The seasonal abundance of $S$. oleae was studied for two successive years from 2009-2010 on olive trees in El-Arish. The obtained results showed that, the insect population reached maximum during mid of August (9729/ 60 leaves/30 twigs) in first year and mid of September (6899/60 leaves/30 twigs) in the second year. Numbers by the parasitoids, Metaphycus helvolus (Compere), Microterys flavus (Howard) and the predators, Coccinella undecimpunctata L. and Exochomus flavipes Thunb., reached maximum (22,5,8 and $28 / 60$ leaves/30 twigs) during August, August ,September and August, in the first year, respectively and 24,19,4 and 22 during September in the second year, respectively.

Keywords: Ecology,Sassetia spp.,Coccidae, natural enemies,Egypt

\section{INTRODUCTION}

The Genus Saissetia Deplanche (Coccidae: Coccoidae: Hemiptera) represented in Egypt by two species. These are the soft brown scale,, Saissetia coffeae (Walker) and the Mediterranean black scale, Saissetia oleae (Olvier) (Abd-Rabou, 2000).

The damage of Saissetia spp., feed on plant juices, cause a loss of vigor, spots on the foliage due to toxins in the scale saliva, deformation of infested plant parts, loss of leaves, retarded plant growth, even death of the plant and causing premature death of pointed gourd vines (Valand et al., 1989 and Carvalho et al., 2003). Saissetia spp. are the most serious soft scale insects infesting fruit trees in Egypt (El-Minshawy et al., 1971,1974 and Abd El-Razak, 2000). 
The hemispherical scale, S. coffeae had three generations (El-Minshawy and Saad, 1977), 3-4 peaks (Hanafi, 1977), three generations ( El-Agamy et al. ,1994), two duration's of activity (Hendawy,1999) and three and two periods of activity (Moursi,2010). Abd- Rabou et al. (2009) studied the biological aspects of S. coffeae . The parasitoids are considered one of the most effective bioagents of $S$. coffeae (ElMinshawy and Saad, 1977; El-Minshawi et al.,1978; Abd-Rabou, 2001b and Moursi , 2010).

The Meditterranean soft black scale Saissetia oleae (Olivier) (Hemiptera: Coccidae) had 6 host plant species (Abd El-Razak,2000). This soft scale insect distributed all over Egypt (Mohammed and Nada ,1991). Also the parasitoids has a good role in controlling S.oleae (El-Minshawi et al., 1978; Abd-Rabou, 2001a; AbdRabou, 2004,a, b, andTena et al.,2008). In the other hand the predators of Sassetia spp. were recorded and studied by Abd Allah (1988), Hamed and Hassanein (1991), El-Agamy et al. (1994) and Abd-Rabou et al. (2003).

The present work dealt with the ecological aspects of Saissetia spp. and its natural enemies in Egypt.

\section{MATERIALS AND METHODS}

Infested leaves and twigs of olive were examined in the field using a pocket magnification lens. Infested leaves and twigs were collected from different host plants and different locations in Egypt during 2009-2010. Identification of Saissetia spp. was done by examining adults in Canada Balsam. Also Infested leaves and twigs will be examined in the field, using a pocket lens. The leaves and twigs will be collected and placed separately in paper bags for further examination in the laboratory. Materials will be kept in a wellventilated container until the emergence of any natural enemies. Identification of natural enemies will be made by examining mounted adults in Hoyer's medium. Abundance of the populations of Saissetia sp. and their natural enemies were carried out on olive trees during 2009 and 2010 in El-Arish and Northern Coast. The plant areas selected for these investigations received no chemical control measures for several years. Twenty trees of olive almost similar in age, size, shape and growth condition were randomly chosen for sampling at twice a week intervals for each location.

On each biweekly sampling, 60 leaves and 15 twigs of olive were chosen at random. Thereafter, the leaves and twigs were kept in a closed paper bags and transferred to the laboratory for further examination and counting. For natural enemies each monthly sampling, 60 leaves and 15 twigs of olive trees were chosen randomly. Each leaf and twig were stored in a well-ventilated emergence glass tube and monitored daily for parasitoid emergence. Rate of parasitism was determined by dividing the number of emerging parasitoid from each by the number of hosts existing. Predators was counted in filed and transferred to the laboratory for further examination. Simple correlation and regression values were calculated to obtain information about the relationships between the three tested weather factors and the population of the pest and its natural enemies.

\section{RESULTS AND DISCUSSION}

\section{A list of Genus Saissetia in Egypt:}

a. The soft brown scale,, Saissetia coffeae (Walker)

b. The Mediterranean black scale, Saissetia oleae (Olvier) 


\section{A list of parasitoids of Genus Saissetia in Egypt:}

Family: Aphelinidae Coccophagus lycimnia (Walker),C. scutellaris (Dalman), Marietta leopardina Motschulsky., Family: Encyrtidae., Baeoanusia sp., Diversinervus elegans Silvestri., Encyrtus inflelix (Embleton), M. flavus (Howard). M. helvolus (Compered), M. lounsburyl (Howard), M. zebratus (Mercet), Microterys flavus (Howard), Parechthrodryinus coccidiphagus (Mercet)., Family: Mymaridae. Alaptus sp., Family: Pteromalidae. Scutellista cyanea Motschulsky.

\section{List of predators of Genus Saissetia in Egypt:}

\section{Coleoptera:}

Family: Coccinellidae ,Chilocorus bipustulatus L.,Coccinella septempunctata (L.), Coccinella undecimpunctata L., Cydonia vicina isis , Exochomus flavipes Thunb. Pharoscymnus various Kirsch, Rodalia cardinals Muls., Scymnus syriacus Mars. Scymnus interruptus Goez, Family: Staphylinidae, Paederus alfierii Koch

\section{Diptera:}

Family: Syrphidae, Syrphus corollae Fab., Metasyrphus corollae Fab. (Diptera), Paragus compeaitus Wied. (Diptera), Hemiptera, Family : Anthocoridae Orius laevigatus Fieb., O. albidipennis, Neuroptera, Family: Chrysopidae Chrysoperlla carnae Steph.,

\section{Ecological studies of Genus Saissetia in Egypt:}

\subsection{The hemispherical scale, Saissetia coffeae (Walker):}

\subsubsection{Host Plants:}

During the present work, Olea europaea was recorded as a host plant of $S$. Coffeae. It is the most serious soft scale insects infesting guava trees in Alexandria (El-Minshawy et al., 1971 and 1974). Abd El-Razak (2000) reported S. Coffeae from one plant species .

\subsubsection{Distribution:}

During the present work this species was recorded distributed in four governorates. These are Alexandria, Mersa Matruh, North and South Sinai. Soft scale insects distributed all over Egypt. Mohammed and Nada (1991) recorded the Egyptian soft scale from Assiut, Aswan, Alexandria, Beheira, Cairo, Dakahlyia, Demietta, Wastern desert, El-Minya, Gharbiya, Giza, Fayoum, Ismailia, Kafr El-Sheikh, Menoufiya, Qalyubiya, Qena, Sharkiya, Sinai, Siwa Oasis and Suez.

\subsubsection{Natural enemies:}

\subsubsection{Parasitoids:}

Eight species of aphelinids, encyrtids and pteromalids were recorded and collected from concerned specimen under investigation here found in Egypt. These are: Coccophagus lycimnia (Wlker), C. scutellaris (dalman), E. inflelix (Embleton), Marietta leopardina Motschulsky, Metaphycus helvolus (Compere), M. lounsburyi (Howard), Microterys flavus (Howard) and Scutellista cyanea Motschulsky.

\subsubsection{Predators:}

Twelve species of predators were recorded and collected from concerned specimen under investigation here found in Egypt. These are Coleoptera: Family: occinellidae, Coccinella septempunctata (L.), Exochomus flavipes Thunb., Pharoscymnus various Kirsch., Scymnus syriacus Mars., Scymnus interruptus Goez,Family: Syrphidae, Metasyrphus corollae Fab. (Diptera),Paragus compeaitus Wied. (Diptera), Hemiptera, Family: Anthocoridae, 8. Orius laevigatus Fieb., Neuroptera Family : Chrysopidae Chrysoperlla carnae Steph. 


\subsubsection{Abundance of Saissetia coffeae in Egypt:}

The seasonal abundance of $S$. coffeae was studied for two successive years from 20092010 on olive trees in Northern Coast .The obtained results in Fig. (1) showed that, the insect population reached maximum during mid September (7728 and 8368/60 leaves/30 twigs ) in first year and second year, respectively. Numbers by paraitoids Metaphycus lounsburyi (Howard), Microterys flavus (Howard) and Scutellista cyanea Motschulsky and a predator Scymnus syriacus Mars., reached maximum (31,9,3 and 19/60 leaves/30 twigs) during September ,July, September and August, in the first year, respectively and 20,8,2 and 15 during September in the second year, respectively (Figs. $2 \& 3$ ).

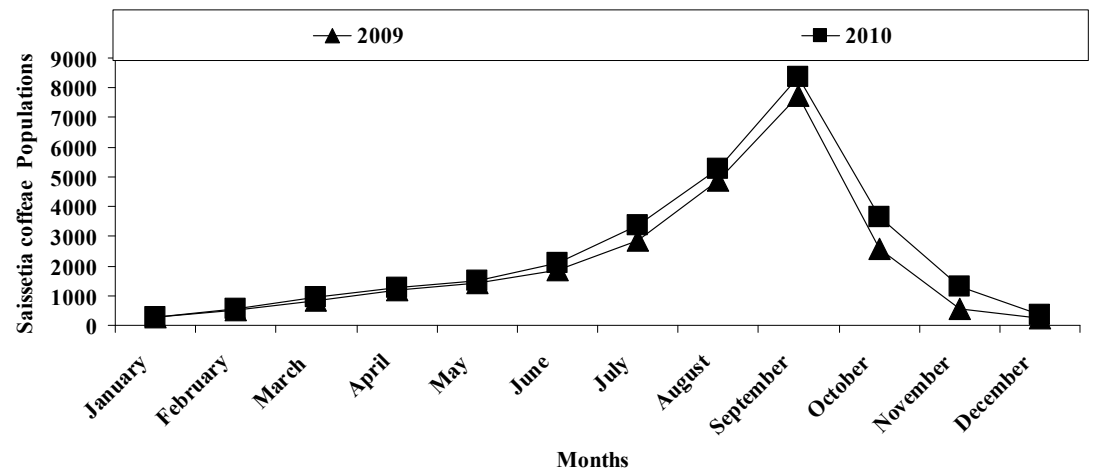

Fig (1): Population dynamics of the soft brown scale, Saissetia coffeae on olive trees in Northern Coast region during 2009 and 2010.

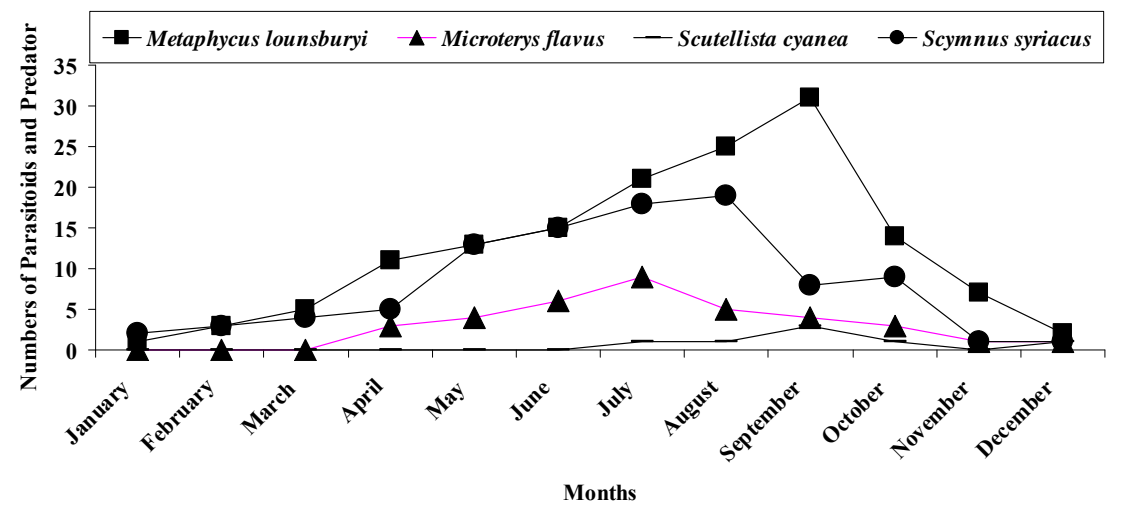

Fig.(2):Population dynamics of parasitoids and predator of soft brown scale, Saissetia coffeae on olive trees in Northern Coast region during 2009.

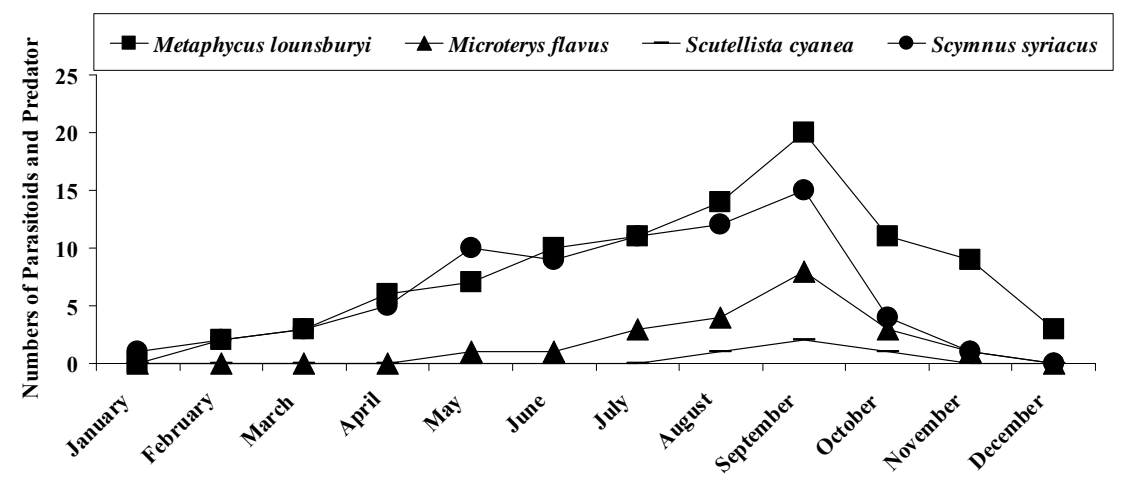

Months

Fig.(3):Population dynamics of parasitoids and predator of soft brown scale, Saissetia coffeae on olive trees in Northern Coast region during 2010. 
Data in Table (1), show that the simple correlation between the population of Metaphycus lounsburyi, Scymnus syriacus, maximum, minimum temperature, relative humidity\% and the mean number of the soft brown scale, Saissetia coffeae were significant $(\mathrm{r}=0.63,0.60,0.84,0.79$ and 0.81$)$, respectively and non-significant ( $\mathrm{r}=0.41$ and 0.38 ) between Microterys flavus (Howard) and Scutellista cyanea Motschulsky and the mean number of the soft brown scale during the 2009 . Also, results in Table (1), show that the simple regression for changing the population of Metaphycus lounsburyi, Scymnus syriacus, maximum, minimum temperature, relative humidity $\%$ and the mean number of $S$. coffeae were significant $(b=0.62,0.66,0.81$, 0.80 and 0.78$)$, respectively and non-significant $(b=0.37$ and 0.32$)$ between the Microterys flavus (Howard) and Scutellista cyanea Motschulsky and the mean number of the soft brown scale during the 2009.

Table 1: Simple correlation and regression values of the population dynamics of the soft brown scale, Saissetia coffeae and its parasitoid and predator on olive trees in Northern Coast Governorate during 2009.

\begin{tabular}{|l|c|c|c|c|}
\hline \multicolumn{1}{|c|}{ Variable } & $\begin{array}{c}\text { Simple } \\
\text { correlation “r” }\end{array}$ & Probability “P” & Regression & Probability “P” \\
\hline Metaphycus lounsburyi & 0.63 & $*$ & 0.62 & $*$ \\
\hline Microterys flavus & 0.41 & Ns & 0.37 & Ns \\
\hline Scutellista cyanea & 0.38 & Ns & 0.32 & Ns \\
\hline Scymnus syriacus & 0.60 & $*$ & 0.66 & $*$ \\
\hline Maximum & 0.84 & $* *$ & 0.81 & $* *$ \\
\hline Minimum & 0.79 & $* *$ & 0.80 & $* *$ \\
\hline R.H. \% & 0.81 & $* *$ & 0.78 & $*$ \\
\hline
\end{tabular}

Data in Table (2), show that the simple correlation between the population of Metaphycus lounsburyi, Scymnus syriacus, maximum, minimum temperature, relative humidity $\%$ and the mean number of the soft brown scale, Saissetia coffeae were significant $(\mathrm{r}=0.71,0.68,0.87,0.82$ and 0.85$)$, respectively and non-significant $(\mathrm{r}=0.36$ and 0.29 ) between Microterys flavus (Howard) and Scutellista cyanea Motschulsky and the mean number of the soft brown scale during the 2010 . Also, results in Table (2), show that the simple regression for changing the population of Metaphycus lounsburyi, Scymnus syriacus, maximum, minimum temperature, relative humidity $\%$ and the mean number of $S$. coffeae were significant $(b=0.70,0.69,0.85$, 0.84 and 0.73$)$, respectively and non-significant $(b=0.31$ and 0.30$)$ between the Microterys flavus (Howard) and Scutellista cyanea and the mean number of the soft brown scale during the 2010 .

S. coffeae had three generations, during April-May, June-July and AugustSeptember. The third generation overwinters as second nymphal instar from November till February (El-Minshawy and Saad, 1977). While Hanafi in the same year recorded 3-4 peaks for this soft scale. El-Agamy et al. (1994) recorded three generations of $S$. coffeae on guava trees in Kafr El-Sheikh governorate in May, August and October. Hendawy (1999) stated that S. coffeae had two duration's of activity, the first from October to November, while the second from May up to 
August, it is note worthy that the adults (usually females) are absent from December to February; Moursi (2010) found S. coffeae had three and two periods of activity during the first and second seasons, respectively.

Table 2: Simple correlation and regression values of the population dynamics of the soft brown scale, Saissetia coffeae and its parasitoid and predator on trees in Northern Coast Governorate during 2010.

\begin{tabular}{|l|c|c|c|c|}
\hline \multicolumn{1}{|c|}{ Variable } & $\begin{array}{c}\text { Simple } \\
\text { correlation } \\
\text { "r" }\end{array}$ & $\begin{array}{c}\text { Probability } \\
\text { "(P" }\end{array}$ & Regression & $\begin{array}{c}\text { Probability } \\
\text { "P" }\end{array}$ \\
\hline Metaphycus lounsburyi & 0.71 & $*$ & 0.70 & $*$ \\
\hline Microterys flavus & 0.36 & Ns & 0.31 & Ns \\
\hline Scutellista cyanea & 0.29 & Ns & 0.30 & Ns \\
\hline Scymnus syriacus & 0.68 & $*$ & 0.69 & $*$ \\
\hline Maximum & 0.87 & $* *$ & 0.85 & $* *$ \\
\hline Minimum & 0.82 & $* *$ & 0.84 & $* *$ \\
\hline R.H. \% & 0.85 & $* *$ & 0.83 & $* *$ \\
\hline
\end{tabular}

El-Minshawy and Saad (1977) mentioned that Scutellista cyanea Motsch, was the most important enemy attacking $S$. coffeae. This parasitoid was prevent on $S$. coffeae and S. oleae from August to November and on C. floridensis in March and September (El-Minshawi et al., 1978). Abd-Rabou (2001b) studied the dynamic of the hemispherical scale, Saissetia coffeae (Walker) in Alexandria. He recorded the total rate of parasitism reached $27.0 \%$, out of which $M$. helvolus was responsible for $13 \%$. In the Northern Coast region, the total rate of parasitism reached $31.9 \%$ out of which C. lycimnia was resposible for $10.6 \%$. M. helvolus was collected from all investgated locations. Moursi. (2010) found S. coffeae associated with six parasitoids, Coccophagus lycimnia Walker, Encyrtus inflex (Embleton), Metaphycus helvolus Comp., Microterys flavus (Howerd), Scutellista cyanea Motch. and Eublemma scitula Ramb. The hyperparasitoid, Marietta leopardina Motch. was also found associated with $S$. Coffeae.

Abd Allah (1988) recorded that the coleopterous insect predators feeding on soft scale infesting citrus, mango and ledge plants in Mansoura region were Cydonia vicina isis Cr., Cydonia vicina nilotica Muls., Coccinella septempunctata L., C. undecimpunctata, Scymnus interruptus Goez, S. cyriacus, Exochomus flavipes Thunb., Rodalia cardinalis Muls. And Paederus alfierii Koch. He added two neuropetrous predators, Chrysopa carnea Steph. And C. septempunctata Wesm.; two hemipterous predators, Orius laevigatus Fieb. And O. albidipennis and two dipterous predators, Metasyrphus corollae Fab. and Paragus compeaitus Wied. The predators, C. bipustulatus, S. syriacus, Pharaoscymnus Varius Kirsch and $R$. cardinalis were found feeding on some soft scale insects and Chrysop sp. larvae are very common and polyphagous predators feeding on many soft scale insects (Hamed and Hassanein, 1991). C. bipustulatus, S. syriacus, C. carnea, C. septempunctata and Orius laevigatus Fab. Recorded associated with different species of soft scale insects in Kafr El-Sheikh (El-Agamy et al., 1994). 


\subsection{The Mediterranean black scale, Saissetia oleae (Olvier)}

\subsubsection{Host Plants:}

During the present work, Olea europaea was recorded as a host plant of S. oleae. The Meditterranean soft black scale S. oleae is a cosmopolitan and polyphagous soft scale pest of more than 60 plant species in the Mediterranean region, including citrus and olives (Carvalho et al. 2003). Abd El-Razak (2000) reported S. oleae (Oliver) from 6 host plant species.

\subsubsection{Distribution:}

During the present work this species was recorded distributed in three governorates. These are Mersa Matruh, North and South Sinai. Soft scale insects distributed all over Egypt. Mohammed and Nada (1991) recorded the Egyptian soft scale from Assiut, Aswan, Alexandria, Beheira, Cairo, Dakahlyia, Demietta, Wastern desert, El-Minya, Gharbiya, Giza, Fayoum, Ismailia, Kafr El-Sheikh, Menoufiya, Qalyubiya, Qena, Sharkiya, Sinai, Siwa Oasis and Suez.

\subsubsection{Natural enemies:}

\subsubsection{Parasitoids:}

Twelve species of aphelinids, encyrtids, mymarids and pteromalids were recorded and collected from concerned specimen under investigation here found in Egypt.These are: Alaptus sp., Baeoanuisa sp., Coccophagus lycimnia (Walker), Diversinervus elegans Silvestri, Marietta leopardina Motschulsky, Metaphycus flavus (Howard), M. helvolus (Compere), M. zebratus (Mercet), Microterys flavus (Howard), Parechthrodryinus coccidiphagus (Mercet) and Scutellista cyanea Motschulsky.

\subsubsection{Predators:}

Twelve species of predators were recorded and collected from concerned specimen under investigation here found in Egypt. These are Coleoptera: Family: Coccinellidae ,Chilocorus bipustulatus L.,Coccinella septempunctata (L.), Coccinella undecimpunctata L., Cydonia vicina isis, Exochomus flavipes Thunb., Pharoscymnus various Kirsch., Rodalia cardinals Muls., Scymnus syriacus Mars., Scymnus interruptus Goez,Family: Staphylinidae Paederus alfierii Koch Diptera: Family: Syrphidae Syrphus corollae Fab. Metasyrphus corollae Fab. (Diptera) Paragus compeaitus Wied. (Diptera) Hemiptera Family : Anthocoridae Orius laevigatus Fieb. O. albidipennis Neuroptera Family : Chrysopidae Chrysoperlla carnae Steph.

\subsubsection{Abundance of Saissetia oleae in Egypt:}

The seasonal abundance of $S$. oleae was studied for two successive years from 2009-2010 on olive trees in El-Arish.The obtained results in Fig. (4) showed that, the insect population reached maximum during mid of August (9729/ 60 leaves/30 twigs) in first year and mid of September (6899/ 60 leaves/30 twigs) in the second year. Numbers by the parasitoids, Metaphycus helvolus (Compere), Microterys flavus (Howard) and the predators, Coccinella undecimpunctata L. and Exochomus flavipes Thunb., reached maximum (22,5,8 and 28 /60 leaves/30 twigs) during August, August ,September and August, in the first year, respectively and 24,19,4 and 22 during September in the second year, respectively (Figs 5\&6).

Data in Table (3), show that the simple correlation between the population of Metaphycus helvolus, Exochomus flavipes, maximum, minimum temperature, relative humidity $\%$ and the mean number of the soft brown scale, Saissetia coffeae were significant $(\mathrm{r}=0.66,0.71,0.86,0.77$ and 0.74$)$, respectively and non-significant $(\mathrm{r}=$ 0.27 and 0.31 ) between Microterys flavus, Coccinella undecimpunctata and the mean 
number of the soft brown scale during the 2009. Also, results in Table (3), show that the simple regression for changing the population of Metaphycus helvolus, Exochomus flavipes, maximum, minimum temperature, relative humidity $\%$ and the mean number of $S$. coffeae were significant $(b=0.71,0.70,0.84,0.74$ and 0.73$)$, respectively and non-significant $(b=0.25$ and 0.29$)$ between the Microterys flavus, Coccinella undecimpunctata and the mean number of the soft brown scale during the 2009.

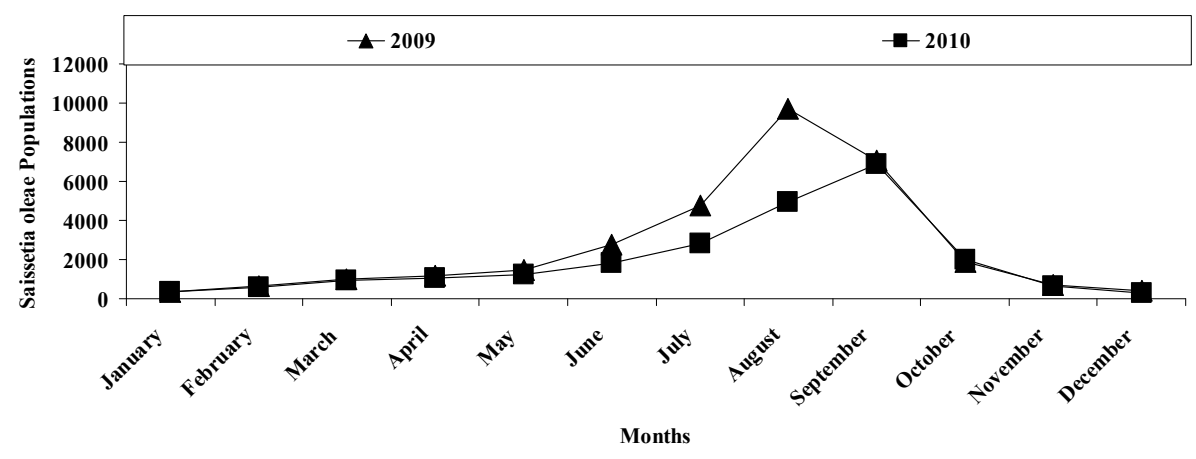

Fig (4): Population dynamics of the Mediterranean black scale, Saissetia oleae on olive trees in Al-Arish region during 2009 and 2010.

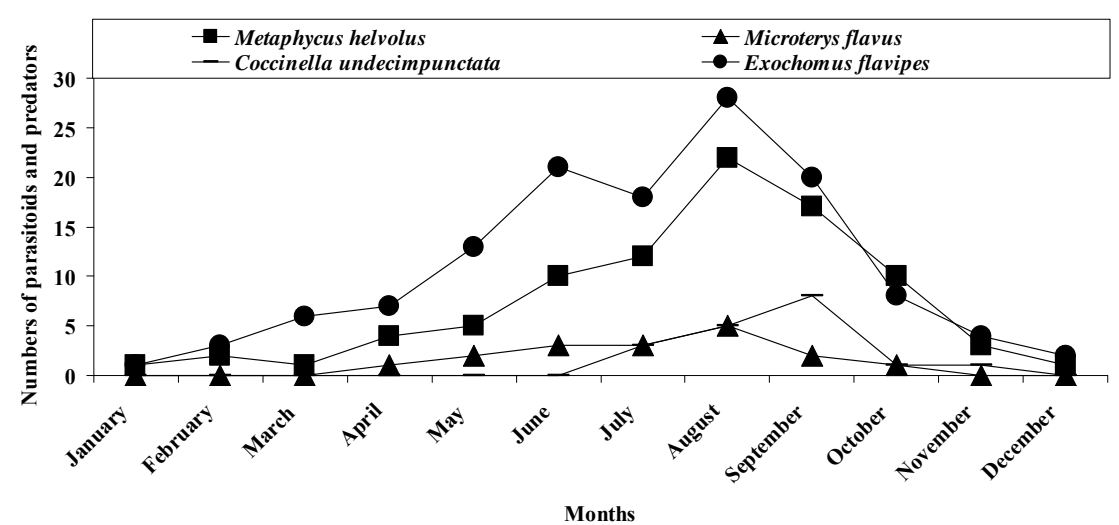

Fig.(5):Population dynamics of parasitoids and predator of the Mediterranean black scale, Saissetia oleae on olive trees in Al-Arish region during 2009.

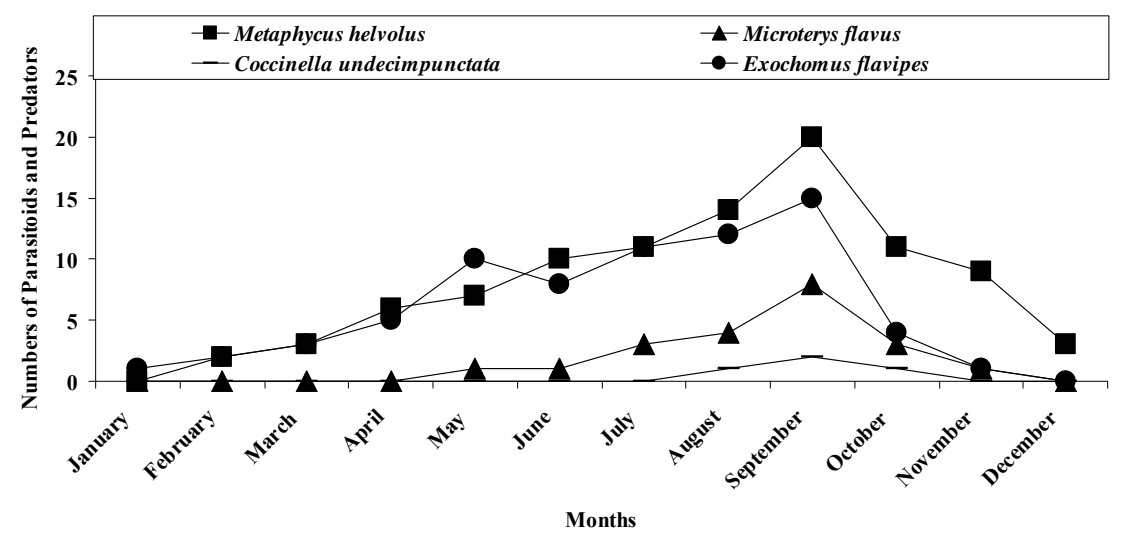

Fig.(6): Population dynamics of parasitoids and predator of the Mediterranean black scale, Saissetia oleae on olive trees in Al-Arish region during 2010. 
Table 3: Simple correlation and regression values of the population dynamics of The Mediterranean black scale, Saissetia oleae and its parasitoid and predator on olive trees in Al-Arish region during 2009.

\begin{tabular}{|l|c|c|c|c|}
\hline \multicolumn{1}{|c|}{ Variable } & $\begin{array}{c}\text { Simple } \\
\text { correlation } \\
\text { "r" }\end{array}$ & $\begin{array}{c}\text { Probability } \\
\text { "P" }\end{array}$ & Regression & $\begin{array}{c}\text { Probability } \\
\text { "P"' }\end{array}$ \\
\hline Metaphycus helvolus & 0.66 & $*$ & 0.71 & $*$ \\
\hline Microterys flavus & 0.27 & Ns & 0.25 & Ns \\
\hline $\begin{array}{l}\text { Coccinella } \\
\text { undecimpunctata }\end{array}$ & 0.31 & Ns & 0.29 & Ns \\
\hline Exochomus flavipes & 0.71 & $*$ & 0.70 & $*$ \\
\hline Maximum & 0.86 & $* *$ & 0.84 & $*$ \\
\hline Minimum & 0.77 & $*$ & 0.74 & $*$ \\
\hline R.H. \% & 0.74 & $*$ & 0.73 & $*$ \\
\hline
\end{tabular}

Data in Table (4), show that the simple correlation between the population of Metaphycus helvolus, Exochomus flavipes, maximum, minimum temperature, relative humidity $\%$ and the mean number of the soft brown scale, Saissetia coffeae were significant $(\mathrm{r}=0.73,0.71,0.89,0.70$ and 0.72$)$, respectively and non-significant $(\mathrm{r}=$ 0.28 and 0.22 ) between Microterys flavus, Coccinella undecimpunctata and the mean number of the soft brown scale during the 2010 . Also, results in Table (4), show that the simple regression for changing the population of Metaphycus helvolus, Exochomus flavipes, maximum, minimum temperature, relative humidity $\%$ and the mean number of $S$. coffeae were significant $(b=0.72,0.62,0.88,0.77$ and 0.75$)$, respectively and non-significant $(b=0.27$ and 0.21$)$ between the Microterys flavus, Coccinella undecimpunctata and the mean number of the soft brown scale during the 2010 .

Table 4: Simple correlation and regression values of the population dynamics of The Mediterranean black scale, Saissetia oleae and its parasitoid and predator on olive trees in Al-Arish region during 2010.

\begin{tabular}{|l|c|c|c|c|}
\hline \multicolumn{1}{|c|}{ Variable } & $\begin{array}{c}\text { Simple } \\
\text { correlation “r” }\end{array}$ & $\begin{array}{c}\text { Probability } \\
\text { “P” }\end{array}$ & Regression & Probability “P” \\
\hline Metaphycus helvolus & 0.73 & $*$ & 0.72 & $*$ \\
\hline Microterys flavus & 0.28 & Ns & 0.27 & Ns \\
\hline Coccinella undecimpunctata & 0.22 & Ns & 0.21 & Ns \\
\hline Exochomus flavipes & 0.71 & $*$ & 0.62 & $* * *$ \\
\hline Maximum & 0.89 & $* *$ & 0.88 & $*$ \\
\hline Minimum & 0.70 & $*$ & 0.77 & $*$ \\
\hline R.H. \% & 0.72 & $*$ & 0.75 & $*$ \\
\hline
\end{tabular}

Abd-Rabou (2001a) conducted a survey of the parasitoids of S. oleae was carried out monthly between April 1995 and March 1997 in three different locations in Egypt. Five species of Encyrtidae, a species of Pteromalidae and an aphelinid 
hyperparasite were found. Three of these records were new for Egypt. The parasitoid, $S$. caerulea was recorded for the first time associated with $S$. oleae by Abd-Rabou (2004a). The parasitoid, S. caerulea which associated with S. oleae infested olive in Northern Coast. The maximum parasitism rate reached 38.2 and $40.9 \%$ during the first and second years, respectively. While average parasitism rates was 21.3 and 23.5 $\%$ during the first and second years, respectively. Later, Abd-Rabou (2004) mass reared and released the parasitoid at monthly intervals in olive groves infested with $S$. oleae at three localities in Egypt and percentages of parasitism increased after releasing from 14 to $35 \%$. Abd-Rabou (2004b) studied the Indigenous parasitoid Metaphycus lounsburyi from different localities in Egypt, were manipulated, reared and mass-produced for classical biological control in Egypt, more than 193,130 parasitoids were released. Several releases were made between May 1999 and April 2001. Increases of the parasitism from 17.4 to 42.0 and from 6.4 to 19.2 during the first year (1999-2000) and the second year (2000-01), respectively, in the Northern Coast. This parasitoid became established in some of the release sites in El-Arish and Matruh Governorates. Tena et al. (2008) Overall, the results show that the most abundant and widely distributed parasitoids of black scale in citrus and olive crops in eastern Spain are S. caerulea, M. flavus and M. lounsburyi. These parasitoids should be considered when determining the side effects of pesticides on beneficials, as an important component of Integrated Pest Management strategies.

Abd-Rabou et al. (2003) recorded 19 predators of S. oleae and studied the population dynamics of six of them. These are C.bipustulatus, Chrysoperla carneae (Stephens), C. undecimpunctata (L.), E. flavipes, Orius sp. and Scymnus syriacus. Two peaks were recorded annually for $C$. bipustulatus and $C$. undecimpunctata while one peak in case of C. carnae and S. syriacus, E. flavips and Orius sp. recorded as a low population throughout the two years under considerations. Abd Allah (1988) recorded that the coleopterous insect predators feeding on soft scale infesting citrus, mango and ledge plants in Mansoura region were Cydonia vicina isis Cr., C. v. nilotica Muls., Coccinella septempunctata L., C. undecimpunctata, Scymnus interruptus Goez, S. cyriacus, Exochomus flavipes Thunb., Rodalia cardinalis Muls and Paederus alfierii Koch. He added two neuropetrous predators, Chrysopa carnea Steph. and C. septempunctata Wesm.; two hemipterous predators, Orius laevigatus Fieb. and O. albidipennis and two dipterous predators, Metasyrphus corollae Fab. and Paragus compeaitus Wied. The predators, C. bipustulatus, S. syriacus, Pharaoscymnus Varius Kirsch and $R$. cardinalis were found feeding on some soft scale insects and Chrysop sp. larvae are very common and polyphagous predators feeding on many soft scale insects (Hamed and Hassanein, 1991). C. bipustulatus, S. syriacus, C. carnea, C. septempunctata and Orius laevigatus Fab. Recorded associated with different species of soft scale insects in Kafr El-Sheikh (El-Agamy et al., 1994).

\section{REFERENCES}

Abd Allah, L. A. (1988): Studies on predator and parasite insects attacking scale insects and mealybugs in Dakahlia governorate. Ph. D. Thesis, Fac. Agric., Mansoura Univ. 
Abd-Rabou, S. (2000): A local outlook to available species of the superfamily Coccoidae (Hemiptera) in Egypt. Annals of Agric. Sc., Moshtohor, 38 (1): 919-930.

Abd-Rabou, S. (2001a): Parasitoids attacking the Mediterranean black scale, Saissetia oleae (Hemiptera: Coccidae) on olive in Egypt. Entomolog. 33(1999): 169-172.

Abd-Rabou, S. (2001b): A survey of parasitoids associated with the hemispherical scale, Saissetia coffeae (Walker) (Hemiptera: Coccidae) in North-west Coastal area of Egypt. Bull. Fac. Agric. Cairo, Univ. Special Edition, 1-5.

Abd-Rabou, S. (2004a): Augmentative releases of indigenous parasitoids of the Mediterranean Black Scale Saissetia oleae (Oliver) (Hemiptera: Coccidae) on olive in Egypt. Shashpa, 11(1):51-56.

.Abd-Rabou, S.(2004b): The role of augmentative releases of indigenous parasitoid Metaphycus lounsburyi (Hymenoptera: Encyrtidae) in enhancing the biological control of Saissetia oleae (Homoptera: Coccidae) on olive in Egypt Archives of Phytopathology and Plant Protection 37(3): 233-237

Abd-Rabou, S.; Hafez, A. and Badary, H. (2003): Survey and dynamics of natural enemies of the Mediterranean Black Scale, Saissetia oleae (Hemiptera: Coccidae) in Egypt. Egyptian J. of Agric. Res. 81(1): 115-123.

Abd-Rabou, S.; Ali, N. and El-Fatih, M. (2009): Life table of the hemispherical scale, Saissetia coffeae (Walker) (Hemiptera: Coccidea). Egypt. Acad. J. Biolog. Sci., 2(2): 165-170.

Abd El-Razak, S. I. (2000): Studies on certain abundant scale insects attacking ornamental plants in public grands. Ph. D. Thesis, Fac. of Agric. University of Alexandria, pp. 204.

Carvalho, P. J.; Torres, L. M.; Pereira, JA. and Bento AA (2003): A cochonilha-negra Saissetia oleae (Olivier,1791) (Homoptera - Coccidae). Instituto Nacional de Investigac, ao Agraria, Universidade de Tras-os-Montes e alto Douro, Escola Superior Agraria de Braganca.

El-Agamy, F. M.; Metwally, S. M. I.; Shawer, M. B. and Metwally, M. M. (1994): The role of parasitoids in the control of Florida wax scale, Ceroplastes floridensis Comst. In Kafr El-Sheikh governorate, Egypt, J. Agric. Res. Tanta Univ., 20 (1): 58-64.

El-Minshawy, A. M.; El-Sawaf, S. K.; Hammad, S. M. and Donia, A. (1971): The biology of Hemiberlesia latanaiae (Sig.). Bull. Ent. Soc. Egypt, 55: 461-7.

El-Minshawy, A. M.; El-Sawaf, S. K.; Hammad, S. M. and Donia, A. (1974): Survey of the scale inestcs attacking fruit trees in Alexandria district 1 (Fam. Diaspididae; Subfam. Diaspidinae, Trib Aspidiotini. Ale. J. Agric. Res 22 (2): 223-32.

El-Minshawy, A. M. and Saad, A. H. (1977): Studies on Saissetia coffeae (Walk.) IIIPopulation fluctuation, seasonal mortality, annual increase in population and number increase in population and number of genrations of $S$. coffeae (Walk.). Alex. J. Agric. Res., 24 (3): 527-32.

El-Minshawy, A.M., Saad, A.H. and Hammad, S.M. (1978): Efficacy of the natural enemy Scutellista cyanea Mostch. (Hym., Pteromalidae) on Sassetia coffeae Wlk., S. oleae (Bern.) and Ceroplastes floridensis Comst. (Hom., Coccidae). Z. Ang. Ent., 85: 31-37. 
Hamed, A. R. and Hassanien, F. A. (1991): Survey of parasitoids and predators of important scale insects, mealybugs and whiteflies in Egypt. Egypt, J. Biol. Pest Control, 1 (2): 147-152.

Hanafi, H. A. (1997): Studies on some scale insects infesting some ornmental plants. Ph. D. Thesisig, Fac. of Agric., Al-Azhar Univ., 126 pp.

Hendawy, A. S. (1999): Studies on ceratin natural enmies of scale insects attacking guava trees at Kafr El-Sheikh governorate. Ph. D. Theisis, Fac. Of Agric., Tanta University, pp 145.

Mohammed, Z. K. and Nada, S. M. A. (1991): Observations on the Coccidae of Egypt (Homoptera: Coccidea: Coccidae). Fourth Arab Congress of Plant Protection, 105-110.

Moursi, G. A. (2010): Seasonal abundance of the hemispherical soft scale insect, Saissetia coffeae (Walker) (Homoptera: Coccidae) and its parasitods on olive in middle Egypt. Egyptian Journal of Biological Pest Control, 20: (2):139-142.

Tena, A.; Soto, A. and Garcia-Mari, F. (2008): Parasitoid complex of black scale Saissetia oleae on citrus and olives: parasitoid species composition and seasonal Trend. BioControl, 53:473-487.

Valand, V.M., Patel, J.I. and Mehta, D.M. (1989): Biology of brown scale Saissetia coffeae) on pointed gourd (Trichosanthes dioica). Indian J. Agric. Sci. 59(9): 610-611.

\section{ARABIC SUMMARY}

$$
\text { معهد بحوث وقاية النباتات ـ مركز البحوث الزرات الباعيةـ الدقي- الجيزةـ مصر }
$$

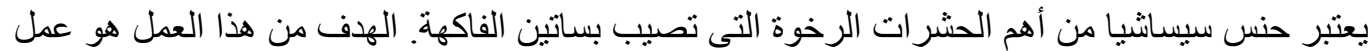

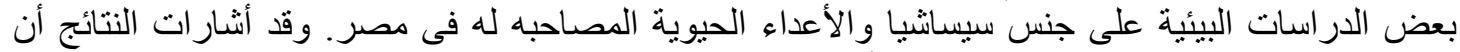

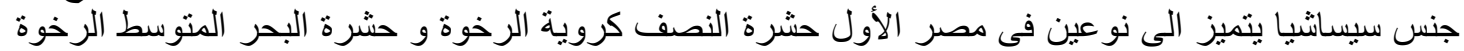

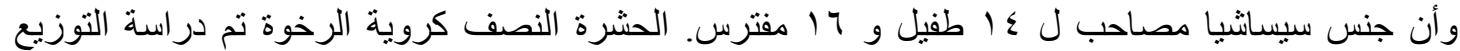

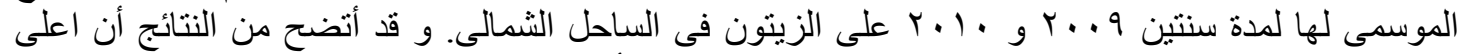

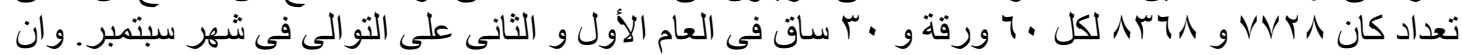

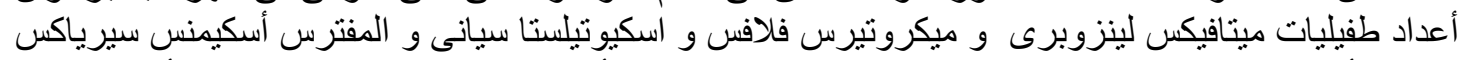

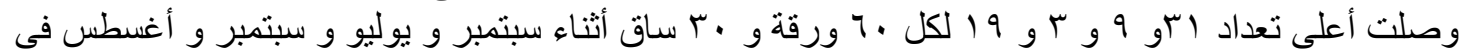

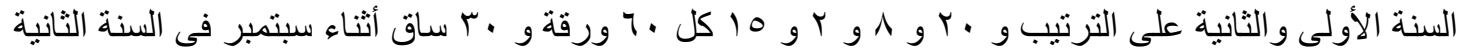

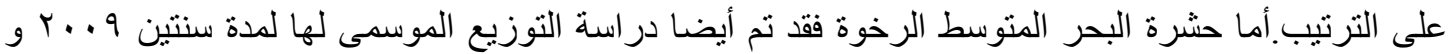

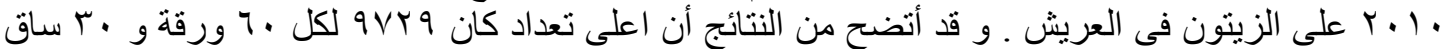

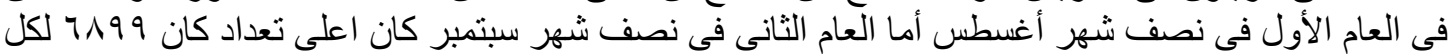

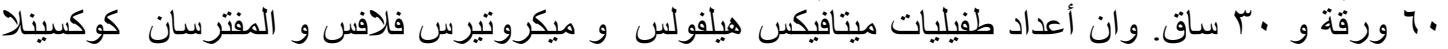

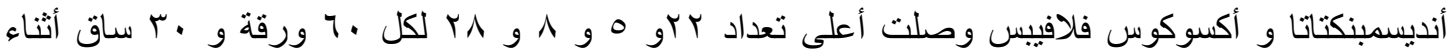

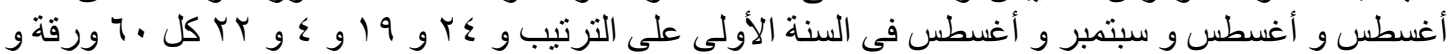
r r ساق أثناء سبتمبر فى السنة الثانية على الترنيب. 